\title{
Effect of Different Planting Pattern of Wheat (Triticum aestivum) and Bean (Vicia faba) on Grain Yield, Dry Matte Production and Weed Biomass
}

\author{
Hamdollah ESKANDARI'), Ahmad GHANBARI ${ }^{2}$ \\ 1) University of Payame Noor, Omidieh Branch,Department of Agriculture,Omidieh, Iran; ehamdollah@gmail.com \\ 2) University of Zabol, Faculty of Agriculture, Department of Agronomy and Plant Breeding, Zabol, Iran
}

\begin{abstract}
An experiment was conducted at the University of London, Kent, UK during the year 2003. The aim of experiment was to investigate the effects of planting pattern on performance of wheat and bean intercrops. A complete randomized block design with four replications was employed to compare the treatments. Treatments included wheat sole crop $(\mathrm{W})$, bean sole crop $(\mathrm{B})$, within row intercropping $\left(\mathrm{M}_{1}\right)$, row intercropping $\left(\mathrm{M}_{2}\right)$ and mix cropping $\left(\mathrm{M}_{3}\right)$. The density of intercropping was according to replacement design (one wheat replaced by three bean plants). The results showed that total dry matter achieved by intercrops was significantly higher than those achieved by either wheat or bean sole crop. Regarding to weed control, intercrops were more effective than sole crops, especially bean sole crop. Crops performance in terms dry weight, height and percentage of leaf, stem pod and ear was affected by cropping systems depending on crop species, where wheat showed more changes compared to bean. Grain yield, harvest index and thousand grain weights of wheat were decreased in intercropping while bean decreased only in grain yield.
\end{abstract}

Keywords: cereals, legume, relative yield total, bean performance, wheat performance, intercropping

\section{Introduction}

Intercropping, the simultaneous growing of two or more crop species on the same piece of land (Ofori and Stern, 1987) is an important practice for the development of sustainable food production systems, particularly in cropping system with limited external inputs (Agegnehu et al., 2006). This may be due to some of the potential benefits for intercropping systems such as high productivity and profitability (Yildirim and Guvence, 2005), improvement of soil fertility through the addition of $\mathrm{N}$ by fixation and extraction from the component legume (HauggaardNielsen et al., 2001), reducing damage caused by pests, diseases and weeds (Banik et al., 2006; Sekamatte et al., 2003), improvement of forage quality (Agegnehu et al., 2006) and efficient use of environmental resources (Knudsen et al., 2004; Eskandari and Ghanbari, 2010) through the complementary effects of two or more crops grown simultaneously on the same area of land.

It is generally understood that the combinations of a legume and cereal are most common among farmers in the semi-arid tropics and would benefit them in resource limiting condition, compared with corresponding sole crops. Yield advantages have been recorded in many legumecereal intercropping systems, including soybean-sorghum (Ghosh et al., 2009), cowpea-maize (Eskandari and Ghanbari, 2009), fababean-wheat (Ghanbari-Bonjar, 2000) and vetch-oat (Tuna and Orak, 2007). The reason of yield advantage of intercropping are mainly that environmental resources such as water, light and nutrients can be utilized more efficiently in intercropping than in the respective sole cropping systems (Liu et al., 2006). The underlying principle of better environmental resource use in intercropping is that if crops differ in the way they utilize resources when grown together, they can complement each other and make better combined use of resources than they grown separately (Willey, 1990). The planting pattern is an agronomic practice which may affect the interaction between the component crops of intercropping and so affects their use of environmental resources and, as a result, the success of intercropping compared with sole cropping systems. Thus, this experiment was designed to quantify the effects of planting pattern on benefits of intercropping in terms of (i) grain yield, (ii) dry matter production and (iii) weed biomass.

\section{Materials and methods}

Site

A randomized complete block design (RCBD) with four replications was carried out during the 2003 growing season on Prescott field on Wye College farm, University of London, Kent, UK $\left(51^{\circ} 11^{\prime} \mathrm{N}, 0^{\circ}, 57^{\prime} \mathrm{E}\right.$, altitude $40-50$ $\mathrm{m}$ above sea level). Details of field and soil characteristics and meteorological data of experimental site are given in Tab. 1 and Tab. 2.

\section{Crop management}

The site of experiment was ploughed to $0.25 \mathrm{~m}$ depth after the removal of the previous crop (forage maize) followed by harrowing in the early autumn prior to drilling the trail. The wheat cultivar Maris Widgeon was selected 
112

Tab. 1. Physical and chemical characteristics of the soil of experimental field

\begin{tabular}{ccccccccc}
\hline Depth $(\mathrm{cm})$ & $\mathrm{pH}$ & $\mathrm{N}\left(\mathrm{mg}_{\mathrm{kg}} \mathrm{kg}^{-1}\right)$ & $\mathrm{P}\left(\mathrm{mg}_{\mathrm{kg}}{ }^{-1}\right)$ & $\mathrm{K}\left(\mathrm{mg} \cdot \mathrm{kg}^{-1}\right)$ & $\mathrm{Ca}\left(\mathrm{mg} \cdot \mathrm{kg}^{-1}\right)$ & $\mathrm{Mg}\left(\mathrm{mg} \cdot \mathrm{kg}^{-1}\right)$ & Texture & Organic matter $(\%)$ \\
\hline $0-60$ & 8.0 & 2.06 & 40.16 & 175.16 & 3153.15 & 61.4 & Silt loam & 4.5 \\
\hline
\end{tabular}

Tab. 2.The meteorological data for wheat-bean intercropping area in 2003

\begin{tabular}{ccccccccccccc}
\hline Month & January & February & March & April & May & June & July & August & September & October & November & December \\
\hline Temperature & 5.06 & 4.94 & 7.26 & 8.74 & 12.04 & 14.35 & 17.07 & 17.57 & 14.42 & 10.82 & 7.28 & 5.08 \\
Rainfall & 76.6 & 47.68 & 35.53 & 52.21 & 34.79 & 59.81 & 38.24 & 68.80 & 70.32 & 75.25 & 81.30 & 76.09 \\
\hline
\end{tabular}

because of popularity of this taller cultivar with organic growers. It also was hypothesized that long straw might reduce competitive shading by the beans. All wheat seeds were treated with Panactine for production against important seed-borne diseases. The bean cultivar chosen was Punch. Wheat and bean were sown to a depth of approximately 3 and $5 \mathrm{~cm}$ respectively by hand in October 20 . Seed rates of 48 and 480 per $\mathrm{m}^{2}$ of bean and wheat were sown to allow for thinning down to an approximate plant population at 32 and 400 plant $\mathrm{m}^{2}$. The plots size was 10.2 $\mathrm{m}^{2}(1.7 \times 6 \mathrm{~m})$ and were drilled longitudinally. Treatments were separated by a $2 \mathrm{~m}$ buffer zone.

At harvest time, plants were cut to $2 \mathrm{~cm}$ above the soil surface and separated by hand into wheat and bean. Each plant was separated into its parts and dried in the oven at $70^{\circ} \mathrm{C}$ for $48 \mathrm{~h}$ and weighed. The performance of each crop was determined by calculating the dry weight, height and the percentage of leaf, stem and pod for bean and dry weight, height and the percentage of leaf, stem and ear for wheat. Grain yield, harvest index and thousand grain weights were also determined for each crop.

\section{Experimental design}

Five treatments including two monocultures of wheat (W) and bean (B) and three mixtures of wheat and bean (Alternate-row intercrop $=\mathrm{M}_{1}$; Within-row intercrop $=\mathrm{M}_{2}$ and Mixed intercrop $=\mathrm{M}_{3}$ ) were compared in the experiment. The experimental design was a randomized complete block (RCB) with four replications. The intercrop composition was based on the replacement design (Snaydon, 1991), in which total population of intercrop components were half of their sole crops.

\section{Statistical analysis}

The analysis of variance of the data was carried out, using MSTATC software. Treatment mean differences were separated by the least significant difference (LSD) test at 0.05 probability level.

\section{Calculation of competitive ratio}

The competitive ability of bean for nutrients to wheat was evaluated by calculating the competitive ratio of bean with respect to wheat $\left(\mathrm{RC}_{\mathrm{b}}\right)$ or competitive ratio of wheat with respect to bean $\left(\mathrm{RC}_{\mathrm{w}}\right)$ (Willey, 1979):

$$
\mathrm{CR}_{\mathrm{b}}=\left(\mathrm{Y}_{\mathrm{ab}} / \mathrm{Y}_{\mathrm{aa}} \div \mathrm{Y}_{\mathrm{ba}} / \mathrm{Y}_{\mathrm{bb}}\right) \times \mathrm{Z}_{\mathrm{ab}} / \mathrm{Z}_{\mathrm{ba}}
$$

In which:

$\mathrm{CR}_{b}$ : Competitive ratio of bean with respect to wheat

$\mathrm{Y}_{\mathrm{ab}}$ : Nutrient uptake by bean in intercropping

$Y_{2 a}$ : Nutrient uptake by bean in sole crop

$\mathrm{Y}_{\mathrm{ba}}$ : Nutrient uptake by wheat in intercropping

$\mathrm{Y}_{\mathrm{bb}}$ : Nutrient uptake by wheat in sole crop

$\mathrm{Z}_{\mathrm{ab}}$ : Part of intercropping allocated to bean

$\mathrm{Z}_{\mathrm{ba}}^{\mathrm{a}}$ : Part of intercropping allocated to wheat

Since the CR values of the two crops will in fact the reciprocal of each other, it will often be sufficient to consider the values of only one (Willey, 1990). This ratio value gives the exact degree of competition, by indicating the number of times in which the dominant species is more competitive than the recessive species.

\section{Results and discussions}

Dry weight of all three intercrops were significantly $(\mathrm{P}<0.05)$ greater than those of sole crops (Tab. 3$)$ and exceeded the expected yield [(sole bean yield + sole wheat $) / 2$ ] There were no significant differences between intercrops grown with different planting patterns. Bean sole crop produced significantly greater dry weight than wheat sole crop. The mean dry weight averaged over intercrops was 2.35 and 1.10 times that of sole wheat and sole bean, respectively (Tab. 3).

The weed biomass in the bean sole crop was significantly $(\mathrm{P}<0.05)$ greater than in wheat sole crop and intercrops. Weed dry weight showed no significant differences between different intercrop planting patterns $\left(M_{1}, M_{2}\right.$ and $M_{3}$ ). Weed dry weight in intercrops was greater than that for sole wheat, but apart from $\mathrm{M}_{3}$ not significantly greater than of sole wheat (Tab. 3).

The bean dry weight was significantly $(\mathrm{P}<0.01)$ reduced by intercropping (Tab. 4). The bean dry weight between different intercrops was statistically similar. The mean bean dry weight averaged over three intercrops was 77.95 of sole cropped bean.

Bean height was significantly $(\mathrm{P}<0.01)$ influenced by cropping system (Tab. 4). The mean of intercropped bean height was significantly $19.47 \mathrm{~cm}$ shorter than for sole cropped bean. Significant differences were not seen between different intercrop treatments (Tab. 4). In this experiment the winter bean plants $(160 \mathrm{~cm})$ wee taller than winter wheat plants $(113.6 \mathrm{~cm})$ (Tab. 4 and Tab 6). 
Tab. 3. Effect of different cropping system on crops dry weight (t. ha $\left.{ }^{-1}\right)$ and dry weight of weed $\left(\mathrm{kg} \cdot \mathrm{ha}^{-1}\right)$

\begin{tabular}{cccccccc}
\hline $\begin{array}{c}\text { Cropping } \\
\text { system* }\end{array}$ & $\mathrm{B}$ & $\mathrm{M}_{1}$ & $\mathrm{M}_{2}$ & $\mathrm{M}_{3}$ & $\mathrm{~W}$ & Mean & $\begin{array}{c}\mathrm{LSD} \\
(0.05)\end{array}$ \\
\hline $\begin{array}{c}\text { Crop dry } \\
\text { weight }\end{array}$ & $13.38 \mathrm{~b}$ & $14.94 \mathrm{a}$ & $14.68 \mathrm{a}$ & $14.52 \mathrm{a}$ & $6.24 \mathrm{c}$ & 12.75 & 0.725 \\
$\begin{array}{c}\text { Weeds dry } \\
\text { weight }\end{array}$ & $154.0 \mathrm{a}$ & $40.75 \mathrm{bc}$ & $38.75 \mathrm{bc}$ & $47.75 \mathrm{~b}$ & $25.25 \mathrm{c}$ & 61.30 & 21.8 \\
\hline
\end{tabular}

$\mathrm{B}=$ sole bean; $\mathrm{M}_{1}=$ alternate-row intercrop; $\mathrm{M}_{2}=$ within-row intercrop;

$\mathrm{M}_{3}=$ mixed intercrop; $\mathrm{W}=$ sole wheat

Percentage of leaf, stem and pod was not significantly $(\mathrm{P}<0.05)$ affected by cropping system. However percentage of leaf and pods with intercropped bean tended to be greater than that for sole cropped beans, but the percentage of stem in sole cropped beans was greater than intercropped beans. This latter difference could be because the stem height of sole cropped bean was significantly $(\mathrm{P}<0.05)$ taller than for intercropped bean (Tab. 4).

Tab. 4. Effect of different cropping system on bean performance

\begin{tabular}{ccccccc}
\hline $\begin{array}{c}\text { Cropping* } \\
\text { system }\end{array}$ & $\mathrm{B}$ & $\mathrm{M}_{1}$ & $\mathrm{M}_{2}$ & $\mathrm{M}_{3}$ & Mean & $\begin{array}{c}\text { LSD } \\
(0.05)\end{array}$ \\
\hline $\begin{array}{c}\text { Dry matter } \\
\text { yield }\left(\mathrm{t} . \mathrm{ha}^{-1}\right)\end{array}$ & $13.38 \mathrm{a}$ & $10.42 \mathrm{~b}$ & $10.51 \mathrm{~b}$ & $10.36 \mathrm{~b}$ & 11.2 & 0.449 \\
Height $(\mathrm{cm})$ & $174.5 \mathrm{a}$ & $154.2 \mathrm{~b}$ & $154.7 \mathrm{~b}$ & $156.2 \mathrm{~b}$ & 160.0 & 7.22 \\
\% leaf & 9.5 & 12.3 & 12.4 & 12.0 & 11.6 & $\mathrm{~ns}$ \\
\hline \% stem & 51.8 & 46.6 & 46.6 & 46.0 & 47.8 & $\mathrm{~ns}$ \\
\% pod & 38.6 & 41.0 & 41.0 & 41.9 & 40.6 & $\mathrm{~ns}$ \\
\hline
\end{tabular}

$\mathrm{B}=$ sole bean; $\mathrm{M}_{1}=$ alternate-row intercrop; $\mathrm{M}_{2}=$ within-row intercrop; $\mathrm{M}_{3}=$ mixed intercrop

Bean grain yield $(\mathrm{P}<0.01)$, harvest index $(\mathrm{P}<0.01)$ and thousand grain weight $(\mathrm{P}<0.01)$ wee significantly affected by cropping system (Tab. 5). Grain yield of intercropped bean was significantly $(\mathrm{P}<0.05)$ less than sole cropped bean (Tab. 5).

The mean intercropped grain yield averaged over intercrops was $86.45 \%$ of sole copped bean. Both HI and TGW wee significantly $(\mathrm{P}<0.05)$ improved by intercrops compared to bean sole cops. For grain yield, HI and TGW there were no significant $(\mathrm{P}<0.05)$ differences between intercrop treatments (Tab. 5).

Copping system significantly $(\mathrm{P}<0.01)$ influenced wheat dry weight. Dry matter weight of intercropped

Tab. 5. Effect of different cropping system on bean grain yield, harvest index (HI) and thousand grain weight (TGW)

\begin{tabular}{ccccccc}
\hline $\begin{array}{c}\text { Cropping } \\
\text { system* }\end{array}$ & $\mathrm{B}$ & $\mathrm{M}_{1}$ & $\mathrm{M}_{2}$ & $\mathrm{M}_{3}$ & Mean & $\begin{array}{c}\mathrm{LSD} \\
(0.05)\end{array}$ \\
\hline $\begin{array}{c}\text { Grain yield } \\
\left(\mathrm{t} . \mathrm{ha}^{-1}\right)\end{array}$ & $4.85 \mathrm{a}$ & $4.23 \mathrm{~b}$ & $4.13 \mathrm{~b}$ & $4.21 \mathrm{~b}$ & 4.35 & 0.416 \\
$\mathrm{HI}(\%)$ & $34.30 \mathrm{~b}$ & $41.02 \mathrm{a}$ & $41.57 \mathrm{a}$ & $43.22 \mathrm{a}$ & 40.03 & 4.64 \\
TGW $(\mathrm{g})$ & $398.7 \mathrm{~b}$ & $426.85 \mathrm{a}$ & $431.75 \mathrm{a}$ & $435.15 \mathrm{a}$ & 423.12 & 18.45 \\
\hline
\end{tabular}

$\mathrm{B}=$ sole bean; $\mathrm{M}_{1}$ =alternate-row intercrop; $\mathrm{M}_{2}=$ within-row intercrop; $\mathrm{M}_{3}=$ mixed intercrop
Tab. 6. Effect of dit wheat

\begin{tabular}{ccccccc}
\hline $\begin{array}{c}\text { Cropping } \\
\text { system* }\end{array}$ & $\mathrm{W}$ & $\mathrm{M}_{1}$ & $\mathrm{M}_{2}$ & $\mathrm{M}_{3}$ & Mean & $\begin{array}{c}\text { LSD } \\
(0.05)\end{array}$ \\
\hline $\begin{array}{c}\text { Dryweight } \\
\left(\mathrm{t} . \mathrm{ha}^{-1}\right)\end{array}$ & $6.24 \mathrm{a}$ & $4.5 \mathrm{~b}$ & $4.1 \mathrm{~b}$ & $4.1 \mathrm{~b}$ & 4.77 & 0.581 \\
\hline Height $(\mathrm{cm})$ & $97.2 \mathrm{~b}$ & $119.2 \mathrm{a}$ & $119.2 \mathrm{a}$ & $118.7 \mathrm{a}$ & 113.6 & 2.42 \\
\% leaf & $13.2 \mathrm{~b}$ & $18.17 \mathrm{a}$ & $16.65 \mathrm{a}$ & $15.3 \mathrm{ab}$ & 15.8 & 2.89 \\
\% stem & 57.6 & 58.97 & 59.8 & 59.37 & 58.9 & $\mathrm{~ns}$ \\
\hline \% ear & $29.1 \mathrm{a}$ & $23.5 \mathrm{~b}$ & $25.3 \mathrm{ab}$ & $25.3 \mathrm{ab}$ & 25.2 & 4.51 \\
\hline
\end{tabular}

$\mathrm{W}=$ sole wheat; $\mathrm{M}_{1}=$ alternate-row intercrop; $\mathrm{M}_{2}=$ within-row intercrop; $\mathrm{M}_{3}=$ mixed intercrop

wheat was significantly $(\mathrm{P}<0.05)$ less than sole cropped wheat (Tab. 6). The mean of intercropped wheat dry weight was $67.8 \%$ of that for sole wheat. Dry weight was not significantly changed between intercrops (Tab. 6).

Wheat height was significantly $(\mathrm{P}<0.01)$ increased due to intercropping and the mean plant height of intercropped wheat was significantly $21.8 \mathrm{~cm}$ taller than for sole cropped wheat. However, there were no significant differences between intercrops (Tab. 6).

Percentage of wheat stem was not significantly $(\mathrm{P}<0.05)$ affected by copping system. However, percentage of intercropped wheat was slightly greater than sole cropped wheat but statistically not significant (Tab. 6). This trend could be explained because intercropped wheat was taller than sole cropped wheat.

Percentage of leaf and ear of wheat were significantly $(\mathrm{P}<0.01$ and $\mathrm{P}<0.05$, respectively) influenced by the copping system. Percentage of leaf for intercropped wheat treatments $M_{1}$ and $M_{2}$ was greater than for sole cropped wheat (Tab. 6) but percentage of ear for intercropped wheat treatment $M_{1}$ was less than that for sole cropped wheat.

Grain yield, HI and TGW of wheat wee significantly $(\mathrm{P}<0.01, \mathrm{P}<0.01$ and $\mathrm{P}<0.01$, respectively) influenced by copping system. Intercropped wheat gain yield showed a significant $(\mathrm{P}<0.05)$ reduction when compared to sole cropped wheat. Grain yield of intercropped wheat was $44.35 \%$ of sole copped wheat. There were no significant differences between intercrop treatments. HI and TGW of sole cropped wheat was significantly $(\mathrm{P}<0.05)$ greater than that of intercropped wheat (Tab. 7). Although there were no significant differences between intercrop treatments.

Tab. 7. Effect of different cropping system on wheat grain yield, harvest index (HI) and thousand grain weight (TGW)

\begin{tabular}{ccccccc}
\hline $\begin{array}{c}\text { Cropping } \\
\text { system }\end{array}$ & ${ }^{*} \mathrm{~W}$ & $\mathrm{M}_{1}$ & $\mathrm{M}_{2}$ & $\mathrm{M}_{3}$ & Mean & $\begin{array}{c}\text { LSD } \\
(0.05)\end{array}$ \\
\hline $\begin{array}{c}\text { Grain yield } \\
\left(\mathrm{t} . \mathrm{ha}^{-1}\right)\end{array}$ & $2.33 \mathrm{a}$ & $1.01 \mathrm{~b}$ & $1.98 \mathrm{~b}$ & $1.11 \mathrm{~b}$ & 1.36 & 0.263 \\
$\mathrm{HI}(\%)$ & $30.87 \mathrm{a}$ & $24.9 \mathrm{~b}$ & $24.25 \mathrm{~b}$ & $25.5 \mathrm{~b}$ & 26.38 & 2.036 \\
$\mathrm{TGW}(\mathrm{g})$ & $39.2 \mathrm{a}$ & $35.57 \mathrm{~b}$ & $36.22 \mathrm{~b}$ & $37.3 \mathrm{~b}$ & 37.07 & 1.735 \\
\hline
\end{tabular}

$\mathrm{W}=$ sole wheat; $\mathrm{M}_{1}=$ alternate-row intercrop; $\mathrm{M}_{2}=$ within-row intercrop; $\mathrm{M}_{3}=$ mixed intercrop 
114

The competitive ratio of bean with respect to wheat $\left(\mathrm{CR}_{\mathrm{b}}\right)$ for dry weight was greater than 1.0 (Tab. 8). Also $\mathrm{CR}_{b}$ for grain yield wee greater than 1.0. There was no significant difference between intercrops. The mean $\mathrm{CR}_{\mathrm{b}} \mathrm{av}$ eraged over three intercrops was 1.15 and 2.0 for dry matter and grain yield, respectively indicating the degree to which bean was more competitive than wheat. Therefore it can be concluded that the competitive ability of bean with respect to wheat for grain was greater than that for dry weight.

Tab. 8. Effect of different cropping system on competitive ratio of bean with respect to wheat $\left(\mathrm{CR}_{\mathrm{b}}\right)$

\begin{tabular}{cccccc}
\hline Cropping system & $\mathrm{M}_{1}$ & $\mathrm{M}_{2}$ & $\mathrm{M}_{3}$ & Mean & LSD $(0.05)$ \\
\hline$\left(\mathrm{CR}_{\mathrm{b}}\right)$ for dry weight & 1.08 & 1.18 & 1.19 & 1.15 & 0.161 \\
$\left(\mathrm{CR}_{\mathrm{b}}\right)$ for grain yield & 2.00 & 2.12 & 1.87 & 2.00 & 0.452 \\
\hline
\end{tabular}

$\mathrm{M}_{1}=$ alternate-row intercrop; $\mathrm{M}_{2}=$ within-row intercrop; $\mathrm{M}_{3}=$ mixed intercrop

These results show that dry matter for all intercrop treatments were greater than those of sole crops (Tab. 3). Similar results from cereal-legume intercrops have been reported by other researchers (Lauriault and Kirksey, 2004; Sleugh et al., 2000; Javanmard et al., 2009). One possible explanation for the higher yield of intercrops is the ability of the component crops to exploit different soil layers without competing with each other. There is probably better use of resources such as (i) light, because the response of taller bean ensured good early interception of light in above layer of canopy, (ii) nutrients and water (HauggaardNielsen et al., 2001; Knudsen et al., 2004).

Concerning weed suppression, intercrops showed an advantage over bean sole crops. However mostly there was no significant difference between intercrops and sole wheat (Tab. 3). Advantages of weed suppression have been reported for many intercrops of grain legume and cereal (Haynes and Lee, 1999; Bulson et al., 1997). Since in the present experiment the intercrops gave greater yields and took up more nutrients, one would expect that intercropping is exploiting resources more intensively than the mean of the sole crops (Tab. 3) and should therefore allow less weed growth. Maereka et al. (2009) reported that inclusion of pumpkin in maize intercrops could be have had a synergetic effect on reducing the amount of resource consumption by weeds, resulting in lower weed density and weed biomass in maize-pumpkin intercrops compared to maize pure stands.

The intercropped bean height (Tab.4) was shorter than for their sole crops. Also the dry weight (Tab. 4) and grain yield (Tab. 5) of bean was reduced by intercropping. The mean dry matter and grain yield of intercropped bean was 77.95 and $86.45 \%$ respectively of sole cropped bean (Tab. 4 and Tab. 5). The higher performance of intercropped bean for grain rather dry matter may have been due to the higher HI and TGW of intercropped bean compared to sole cropped bean which was observed here (Tab. 5).
Trenbath (1993) has concluded that intercropping may show greater efficiency in converting available resources to harvestable yield. Either through greater physiological efficiency or change in patterns of dry matter partitioning. This is supported by results of the present experiment as shown in Tab. 4 and Tab. 5. Percentage of stem of sole cropped bean was greater than that for cropped bean but conversely, percentage of pod, HI, and TGW by intercropped bean was greater than sole copped. Willey (1990) concluded that intercropping could increase harvest index. Haris and Natarajan (1987) with cereal-legume intercrops reported that HI was larger for either both or one species in the intercrop compared to their sole crops. Results in the present experiment indicated that such changes in harvest index and TGW could be dependent on species such that taller and dominant species (bean) resulted in higher HI and TGW by intercropping than for sole cropping (Tab. 5). However, the HI and TGW of wheat (recessive species) by intercropping (Tab. 7) were less than those for sole cropping, mainly due to shading by bean.

The mean plant height of intercropped wheat was 21.8 $\mathrm{cm}$ taller than for sole cropped wheat (Tab. 6). This could be due to the shading effect of bean on wheat. In general wheat height by either sole cropping or intercropping was shorter than bean. The dry weight (Tab. 6) and grain yield (Tab. 7) of wheat was reduced by intercropping. The mean of dry matter and grain yield of intercropped wheat was 68.5 and $44.5 \%$, respectively. Of sole cropped wheat. The lower performance of intercropped wheat for grain rather than dry matter may have been due to the lower $\mathrm{HI}$ and TGW of intercropped wheat compared to sole cropped wheat which was observed. This indicates that an inhibitory effect of shading on grain production seemed to be greater than for dry weight.

A depression in dry matter and grain yield due to intercropping in the wheat component was greater than for the bean component, which could be principally due to shading by the companion bean, because winter bean had taller stems and more prostrate leaves compared to winter wheat.

In terms of dry matter and grain yield the competitive ratio of bean in respect to wheat $\left(\mathrm{CR}_{\mathrm{b}}\right)$ was greater than 1.0 (Tab. 8), indicating that winter beans were more competitive than winter wheat. This agrees with the finding of Haynes and Lee (1999) who worked with wheat and bean. The mean $\mathrm{CR}_{\mathrm{b}}$ averaged over three intercrops was 1.15 and 2.0 for dry weight and grain, respectively indicating the number of times which bean was more competitive than wheat. Therefore it can be concluded that the $\mathrm{CR}_{b}$ for grain was greater than that for dry weight (Tab. 8). Bean had a mean height of $160 \mathrm{~cm}$ and wheat of $113.6 \mathrm{~cm}$. Bean leaves were also more prostrate (compared to the relatively erect leaves of wheat), it could therefore be expected that give winter bean would have a greater competitive ability for light than winter wheat. However, it should be borne in mind that the competitive abilities of wheat and bean as 
component crops are also affected by their genotypes and interaction with the environment and season.

\section{Conclusions}

In general it was concluded that the dry weights achieved by the intercrops were greater than those by either bean or wheat sole crops. In terms of dry weight, grain yield bean was more competitive than wheat. Weed biomass was reduced in intercropping system compared to wheat and bean sole crops. Grain yield, harvest index and thousands grain weights of wheat were reduced in intercropping while bean had reduction just for gain yield and its harvest index and thousands grains weight was increased by intercropping. This must be considered as an important aspect of intercropping in selecting the goal of production.

\section{References}

Agegnehu, G., A. Ghizaw and W. Sinebo (2006). Yield performance and land-use efficiency of barley and faba bean mixed cropping in Ethiopian high lands. Eurp. J. Agron. 25: 202-207.

Banik, P., A. Midya., B. K. Sarkar and S. S. Ghose (2006). Wheat and chickpea intercropping systems in an additive series experiment: Advantages and weed smothering. Eurp. J. Agron. 24:325-332.

Bulson, H. A., R. W. Snaydon and C. W. Stopes (1997). Effect of plant density on intercropped wheat and field beans in an organic farming system. J.Agric. Sci. 128:59-71.

Eskandari, H. and A. Ghanbari (2010). Environmental resource consumption in wheat and bean intercropping: Comparison of nutrient uptake and light interception. Notulae Scientia Biologicae 2(3):100-103.

Eskandari. H. and A. Ghanbari (2009). Intercropping of maize and cowpea as whole-crop forage: effect of different planting pattern on total dry matter production and maize forage quality. Notulae Botanicae Horti Agrobotanicae ClujNapoca 37(2):152-155.

Ghanbari-Bonjar, A (2000). Intercropped wheat and bean as a low-input forage. $\mathrm{PhD}$ thesis. Why College. University of London.

Ghosh, P. K., A. K. Tripathi, K. K. Bandyopadhyay and M. C. Manna (2009). Assessment of nutrieny competition and nutrient requirement in soyabean-sorghum intercropping system. Europ. J. Agron. 31:43-50.

Haris, D. and M. Natarajan (1987). Physiological basis for yield advantage in a sorghum-groundnut intercrop exposed to drought.2. Plant temperature, water status and components of yield. Field Crops Res. 23:216-221.

Hauggaard-Nilsen, H., P. Ambus and E. S. Jensen (2001). Temporal and spatial distribution of roots and competition for nitrogen in pea-barley intercrops. A field studies employing ${ }^{23} \mathrm{P}$ techniques. Plant. Soil. 236:63-74.
Haynes, R. and H. C. Lee (1999). Agronomic aspect of wheatbean intercropping in a low input system, pp. 706-707. Proceedings $3^{\text {rd }}$ ESA Congress, Abano-Padova.

Javanmard, A., A. Dabbagh-Mohammadi Nassab, A. Jvanshir, M. Moghaddam and H. Janmohammadi (2000). Forage quality and quantity in intercropping of maize with different legumes as double-cropped. J. Food. Agric. Environ. $7(1): 163-166$.

Knudsen, M. T., H., Hauggaard-Nielsen, B. Jornsgard and E. S. Jensen (2004). Comparison of interspecific competition and $\mathrm{N}$ use in pea-barley, fababean- barley and lupin-barley intercrops grown at two temperate locations. Eurp. J. Agron. 142:617-627.

Lauriault, L. M. and R. E. Kirksey (2004). Yield and nutritive value of irrigated winter cereal forage grass-legume intercrops in the southern high plains, USA. Agron. J. 96:352-358.

Liu, J. H., Z. H. Zeng, L. X. Jiao, Y. G. Hu, Y. Wang and H. Li (2006). Intercropping of different silage maize cultivars and alfalfa. Acta. Agron. Sci. 32:125-130.

Maereka, E. K., R. M. Madakadze and C. Ngakanda (2009). Productivity and weed suppression in maize-pumpkin intercrops in small scale farming communities of Zimbabwe. Afric. J. Crop. Sci. 9:93-102.

Ofori, F. and W. R. Stern (1987). Cereal-legume intercropping systems. Adv. Agron. 41:41-90.

Sekamatte, B. M., M., Ogenga-Latigo and A. Russell-Smith (2003). Effects of maize-legume intercrops on termite damage to maize, activity of predatory ants and maize yields in Uganda. Crop. Prot. 22:87-93.

Sleugh, B., K. J. Moore, J. Ronald-George and C. Brummer (2000). Binary legume-grass mixtures improve forage yield, quality and seasonal distribution. Agron. J. 92:24-29.

Snaydon, R. W. (1991). Replacement and additive designs for competition studies. J. Applied Ecol. 28:934-946.

Trenbath, B. R. (1993). Intercropping for the management of pests and diseases. Field Crops Res. 34:381-405.

Tuna, C. and A. Orak (2007). The role of intercropping on yield potential of common vetch-oat cultivated in pure stand and mixtures. J. Agric. Biol. Sci. 2(2): 14-19.

Willey, R. W. (1979). Intercropping: its importance and research needs. Part $\Pi$. Agronomy and research approaches. Field Crops Res. 32:1-10.

Willey, R. W. (1990). Resource use in intercropping systems. J. Agric. Water. Manage. 17:215-231.

Yildirim, E. and I. Guvence (2005). Intercropping based on cauliflower: more productivity, profitable and highly sustainable. Eurp. J. Agron. 22:11-18. 